\title{
NOTES ON A CASE OF ACUTE INFECTIVE ENDOCARDITIS TERMINATING IN COMPLETE RECOVERY.
}

\author{
By MAURICE DAVIDSON, M.A., M.D. (Oxon.), F.R.C.P. (Lond.).
}

(Physician to the Brompton Hospital; Physician to the Miller General Hospital for South-East London.)

The following case is of interest in so far as it records what is, to say the least of it, a rare experience in the practice of medicine, viz., the complete recovery of a patient from a condition which presented a typical clinical picture of infective endocarditis, the diagnosis of which was supported by the finding of a positive blood culture.

The patient was a healthy well-developed woman of about 35 years of age who was employed on the clerical staff of a general hospital. Her history was, briefly, as follows:-

For several months she had not been feeling in the best of health, and in June, I926, she took a week's sick leave on account of an attack of so-called influenza, for which she was treated at home on the usual lines. She returned to her work at the hospital about the end of June, although she was still not feeling very fit and was complaining of a certain amount of sore throat. After a few days shen began to feel much worse, and as it was obvious that she was unfit to carry on with her work she was admitted to one of the observation wards for further investigation.

On admission (July $5^{\text {th }}$, I926) the temperature was IoI ${ }^{\circ} \mathrm{F}$., the pulse-rate 96, and the respiration-rate 22 . She was complaining of some pain in the chest, and appeared obviously ill. The urine contained a small quantity of protein; diacetic acid was also present.

For a day or two her condition remained about the same, but the temperature continued to rise; she soon began to complain of pain in the joints, and at the end of about a week she became delirious and appeared without doubt to be seriously ill. In view of the clinical history, the possibility of enteric was thought of, the insidious onset of the illness following an alleged attack of influenza, with a gradually rising temperature and a relatively slow pulse-rate, being clinical features which suggested this diagnosis. All confirmatory evidence, however, was lacking, and it became evident that she was suffering from some grave toxæmia, the nature of which was at the moment uncertain, but which suggested the familiar problem of differential diagnosis between typhoid, general miliary tuberculosis, and infective endocarditis. From the subsequent course of the disease, the varying clinical features which presented themselves, and the confirmatory pathological evidence, there would seem to be little doubt that an infective endocarditis was present. The complete notes of the clinical aspect of the case are, unfortunately, lacking, and I have had to rely to some extent upon my memory of the case, but of the outstanding features there is no manner of doubt.

The clinical picture was characterized by the persistence of irregular pyrexia (see Chart), by the presence of murmurs in the cardiac area which altered in character and intensity from day to day, by marked pallor, by drenching sweats, by migrating joint pains, with obvious synovitis, and by extreme delirium. 
No petechial eruptions were observed on the body, there was no obvious gross enlargement of the spleen, nor did clubbing of the fingers appear. The clinical diagnosis of infective endocarditis rested upon the picture of a septicæmic state, to which was added the suggestive evidence afforded by the constantly changing cardiac murmurs, which was one of the most striking phenomena through the acute phase of the disease.

The pathological evidence on the whole appears to us sufficient to support the diagnosis, and to be of sufficient practical interest to reproduce.

July $\quad 8$ th-Total Leucocyte Count $=9,930$.

Differential Count (3 p.m.).

Polymorphonuclears $\quad \ldots \quad \mathbf{7 4 . 5 \%}$

$\left.\begin{array}{lrr}\text { Large Lymphocytes } & \ldots & \mathbf{1 2 . 0} \% \\ \text { Small Lymphocytes } & \ldots & 7.0 \%\end{array}\right\}$ I9.0\%

$\begin{array}{llll}\text { Hyalines } & \ldots & \ldots & 5.5 \%\end{array}$

Eosinophiles $\quad \ldots \quad \ldots .60$.

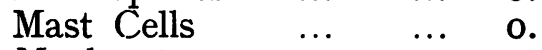

$\begin{array}{llll}\text { Myelocytes } & \ldots & \ldots & \text { I. }\end{array}$

July 8th-Sputum Examination.

"Tubercle Bacilli not seen."

July roth-Blood Culture.

"No growth in 4 days."

Widal Test.

"Agglutination limits to

Typhoid ... ... I in 40

Para. A $\ldots . \quad \ldots$ No agglutination

Para. B ... ... I in Io

These titres are insufficient to establish a positive diagnosis."

Examination of Faces.

"Only normal inhabitants of intestine obtained."

Leucocyte Count.

Total White Cells = I6, Ioo.

Differential Count (I p.m.).

Polymorphonuclears

Large Lymphocytes

Small Lymphocytes

Hyalines

Eosinophiles $\quad \ldots \quad \ldots \quad 0$.

Mast Cells $\quad \ldots \quad \ldots \quad$ o.

$\begin{array}{llll}\text { Myelocytes } & \ldots & \ldots & 0.4 \%\end{array}$

July I2th-Leucocyte Count.

Total White Cells = Io,I50.

Differential Count (6.I5 p.m.).

Polymorphonuclears

Large Lymphocytes

Small Lymphocytes

Hyalines

Eosinophiles

Mast Cells

Myelocytes

$\begin{array}{ccc} & \ldots & 75 \% \\ & \ldots & \\ & \ldots & 6 \% \\ \ldots & \ldots & 4 \% \\ \ldots & \ldots & \text { 2I } \% \\ \ldots & \ldots & 0 . \\ \ldots & \ldots & 0 .\end{array}$


July I3th-Leucocyte Count.

Total White Cells $=8,600$.

Differential Count (9.30 a.m.).

Polymorphonuclears

Large Lymphocytes

Small Lymphocytes

Hyalines

Eosinophiles

Mast Cells

Myelocytes

Throat-Swab.

$$
\begin{array}{lll} 
& \ldots & 78.6 \% \\
& \ldots & 9.2 \% \\
& \ldots & 7.4 \% \\
\ldots & \ldots & 4.8 \% \\
\ldots & \ldots & 0 . \\
\ldots & \ldots & 0 . \\
\ldots & \ldots & 0 .
\end{array}
$$

"The organisms present are chiefly diphtheroid bacilli, with a few colonies of diplococcus crassus, and a few small micrococci. No influenza bacilli or streptococci obtained."

Catheter Specimen of Urine.

"Deposit:-Many red cells and a few leucocytes; much urinary epithelium; a few granular casts.

Culture:-Three colonies of B.Coli."

July I6th-Catheter Specimen of Urine.

"Deposit:-Very occasional oxalate crystals; fairl numerous pus and red blood cells; granular ane epithelial casts, and some urinary epithelium.

Culture:-A few colonies of B.Coli.'

July I7th-Sputum Examination.

" On cultures on blood-agar there were obtained Pneumococci, Friedländer's bacillus, some Gramnegative diplococci (M.catarrhalis). In direct films, a small Gram-positive rod-shaped bacillus was present in addition to the above."

July 24th-Widal Test.

Typhoid $\quad \ldots \quad \ldots \quad$ No agglutination

Para. A $\quad \ldots \quad \ldots \quad$ No agglutination

Para. B $\quad \ldots \quad \ldots \quad$ No agglutination

July 27th-Blood Culture.

"From three separate cultures, taken on two different occasions, there was isolated a coliform bacillus, motile, and fermenting glucose, mannite, and maltose, with acid and gas formation. Indol was not formed in culture. It is not agglutinated by antiserum for typhoid, paratyphoid A. or B., nor is it agglutinated by the patient's blood."

August I3th-Blood Culture. "No growth in culture."

September 7th-Blood Culture. "No growth in 6 days." 
September roth-Leucocyte Count.

Total White Cells $=8,000$.

Differential Count.

Polymorphonuclears

Large Lymphocytes

Small Lymphocytes

Hyalines

Eosinophiles

Mast Cells

Myelocytes

$\begin{array}{rrrr} & \ldots & 53 \% \\ & \ldots & 34 \% \\ & \ldots & 34 \\ \ldots & \ldots & 9 \% \\ \ldots & \ldots & 4 \% \\ \ldots & \ldots & 0 . \\ & & 0 .\end{array}$

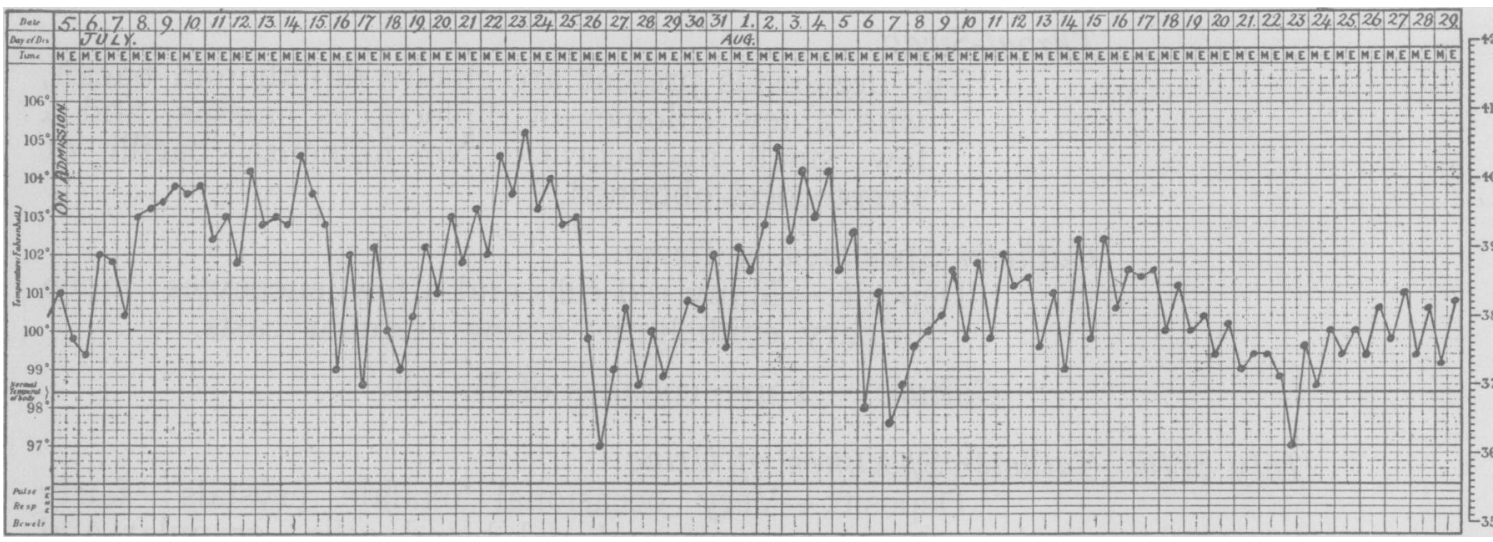

The temperature chart, which is here reproduced, shows the condition of pyrexia up to the end of August, by which time the patient's condition manifested a definite improvement. The fever continued to abate, and by the end of the first week in October was normal. She was discharged from hospital on November $4^{\text {th. }}$.

Comments.-On three occasions was a positive result obtained from the blood culture, and this, together with the clinical evidence, appears to leave no reasonable doubt that this patient was suffering from a definite bacterial endocarditis, from which, contrary to all expectation, she made a complete recovery. It is extremely difficult to form any valid opinion as to how far her recovery can be attributed to the actual therapeutic measures which were employed and how far it must be looked upon as an event which would have happened in any case as a result of successful operation of the defence-mechanism of the body. In the earlier part of the illness she was given an intravenous injection of Hydrarg. Perchlor. gr. $\frac{1}{32}$ on three occasions. Later she was given injections of Acriflavine and also of polyvalent anti-streptococcal serum, administered intravenously. At a still later date the scarlatinal anti-streptococcal serum was tried and the improvement in her general condition undoubtedly seemed to date from this; how far this was a matter of cause and effect or how far it was fortuitous it is, of course, extremely difficult to say. On one occasion (August I6th) a small dose of autogenous vaccine was given; this was followed by a rigor lasting for 20 minutes. The scarlatinal anti-streptococcal serum was given at intervals of about a week until the end of September, when, her condition being altogether very much better, its administration was finally discontinued.

After leaving hospital she was given prolonged sick leave for convalescence. She ultimately returned to her duties and has remained perfectly well and on full work up to the present date. 